\title{
CHAT Gene
}

National Cancer Institute

\section{Source}

National Cancer Institute. CHAT Gene. NCI Thesaurus. Code C104885.

This gene is involved in neurotransmitter biosynthesis. 